\title{
O wyrażeniach na krok i o krok. Przyczynek składniowo-semantyczny
}

Słowa klucze: jednostka leksykalna, semantyka, związek frazeologiczny, współczesny język polski

Poniższy tekst będzie próbą ustalenia granic jednostek leksykalnych ${ }^{1}$ współczesnego języka polskiego konstytuowanych przez wyrażenia na krok i o krok. Wyrażenia te będę omawiać w pewnym stopniu równolegle, ponieważ nie tylko są one do siebie zbliżone semantycznie (w niektórych słownikach traktowane są jako synonimy), ale też łączą je te same problemy natury czysto formalnej i formalno-semantycznej. Chodzi mi przede wszystkim o problem rejestracji ciągu ani jako integralnej części jednostek opisu oraz o funkcjonowanie interesujących mnie ciągów w zdaniach z negacją i bez negacji.

Zdecydowana większość słowników notuje reprezentacje formalne hipotetycznych jednostek, w których znajdujemy sugestię synonimiczności wyżej wymienionych ciągów, np.:

(a) coś nie posunęło się ani na krok, ani o krok (USJP)

(b) na krok, o krok (ISJP)

1 Termin jednostka leksykalna przyjmuję za M. Grochowskim (Grochowski 1982: 28). 
Rzeczywiście, istnieje cała gama kontekstów, w których ciągi te można traktować wymiennie bez jakiejkolwiek zmiany znaczenia całego wypowiedzenia, jednak mówienie w tym miejscu o ich pełnej synonimiczności byłoby wielkim nadużyciem. Postaram się więc wydobyć ograniczenia wymienności tych ciągów, jednak w pierwszej kolejności należy, moim zdaniem, ustalić, jak mają się te ciągi do obiektów leksykograficznych, które analizuję i - przede wszystkim - do jednostek, które konstytuują.

W pierwszej kolejności poruszę kwestię problematycznego ciągu ani, notowanego różnie jako część omawianych tu propozycji jednostek (lub nienotowanego wcale). Problem ten postaram się rozwiązać na przykładzie propozycji jednostki, którą w tym miejscu oznaczę roboczo ciągiem (ani) na $k_{r o k}{ }^{2}$. W takiej formie, tzn. z fakultatywnym ani, notowana jest przez MSJP i WSFzp (w tym drugim wyróżnione są dwie jednostki opisu o tej samej formie). Zaskakujące jest to, że aż w czterech słownikach (USJP, SFzB, SJPSz, SJPDor) ciąg ani został potraktowany jako obligatoryjna część jednostki (bez żadnego oznaczenia), a wystarczy prosty test, by przekonać się, że ciąg ten można pominąć bez żadnego uszczerbku znaczeniowego:

(1) Jan od jakiegoś czasu nie rusza się z domu ani na krok.

(1a) Jan od jakiegoś czasu nie rusza się z domu na krok.

(2) Widzę, że nie ustąpisz mi ani na krok.

(2a) Widzę, że nie ustąpisz mi na krok.

Przyglądając się listom jednostek proponowanym przez słowniki, trafiamy na jeszcze jeden kłopot. Wiele z nich notuje takie jednostki opisu, które w swojej strukturze formalnej zawierają ciąg ani na krok (z fakultatywnym lub obligatoryjnym ani):

(c) Nie ruszyć się skądś krokiem, (ani) na krok (USJP)

(d) Coś nie posunęło się ani na krok, ani o krok (USJP)

(e) Nie odstępować kogoś (ani) na krok (MSJP)

(f) Nie ruszyć się skądś krokiem, (ani) na krok (SFzB)

2 Nie będę analizować tej kwestii osobno dla propozycji jednostki (ani) o krok. Problem rejestracji ciągu ani jako integralnej części tych propozycji jednostek jest, jak sądzę, problemem wspólnym dla (ani) na krok i (ani) o krok. W tym wypadku równoległa analiza byłaby jedynie niepotrzebnym mnożeniem przykładów i nie wprowadziłaby niczego nowego pod względem merytorycznym. 
(g) Nie ustępować komuś ani na krok (SFzB)

(h) Nie odstępować kogo ani na krok (SJPDor)

(i) Nie wychodzić skąd ani na krok (SJPDor)

(j) Nie ruszyć się skądś ani na krok, krokiem (SJPSz)

(k) Coś nie porusza się, nie posuwa się ani na krok (SJPSz)

(1) Nie ruszać się - nie ruszyć się krokiem [(ani) na krok] (WSJP)

Przy założeniu, że jednostką opisu słownikowego ma być byt językowy niepodzielny semantycznie, nie można z aprobatą odnieść się do propozycji (c)-(l). Już na pierwszy rzut oka widać, że wszystkie one są nie jednostkami języka, a połączeniami jednostek, wyodrębnionymi najprawdopodobniej ze względu na częstą łączliwość.

Problem z ciągiem ani najlepiej obrazują niekonsekwencje, które napotykamy w USJP. Jest dla mnie zupełnie niezrozumiałe, dlaczego w propozycji (c) ani zostało uznane za ciąg fakultatywny, natomiast w propozycji (d) potraktowane zostało jako ciąg obligatoryjny. Zdania (3) i (4), choć brzmią może trochę mniej naturalnie, nie wydają się nieakceptowalne:

Ad (d)

(3) Sprawa Romana nie posunęła się na krok.

(3a) Sprawa Romana nie posunęła się ani na krok.

(4) Na krok nie posunąłem się naprzód w sprawie Gelfrerta-Honnefeldera.

(4a) Ani na krok nie posunąłem się naprzód w sprawie Gelfrerta-Honnefeldera.

W podobny sposób można udowodnić fakultatywność ani dla pozostałych propozycji, w których traktuje się ten ciąg jako element obligatoryjny. Por.

$\operatorname{Ad}(\mathrm{g})$

(5) Nie wierz nigdy kobiecie, nie ustępuj na krok, bo przepadniesz z kretesem, nim zrozumiesz swój błąd.

(5a) Nie wierz nigdy kobiecie, nie ustępuj ani na krok, bo przepadniesz z kretesem, nim zrozumiesz swój błąd.

Ad (h)

(6) Helena i Michał nie odstępowali się na krok.

(6a) Helena i Michał nie odstępowali się ani na krok. 
Ad (i)

(7) Na krok nie wychodziliśmy z domu, zabawy w parku i gry na boisku ustały zupełnie, pan Kleks posmutniał i stał się dziwnie małomówny, jednym słowem - wyraźnie zaczęło się coś psuć w naszej Akademii.

(7a) Ani na krok nie wychodziliśmy z domu, zabawy w parku i gry na boisku ustały zupełnie, pan Kleks posmutniał i stał się dziwnie małomówny, jednym słowem - wyraźnie zaczęło się coś psuć w naszej Akademii.

$\operatorname{Ad}(j)$

Por. zdania (1)-(2a)

$\mathrm{Na}$ tym etapie pracy dysponuję więc propozycją jednostki leksykalnej o postaci (ani) na krok oraz - zgodnie z założeniem, że problem ciągu ani jest identyczny dla na krok i o krok - propozycją jednostki o postaci (ani) o krok. Jednak wraz ze stwierdzeniem fakultatywności ani nie rozwiązuję problemu. ISJP w ogóle nie notuje tych jednostek razem z kłopotliwym ciągiem. W słowniku pod red. Mirosława Bańki można za to znaleźć propozycje jednostek o postaci na krok i o krok ilustrowane zarówno przykładami, w których występuje przed nimi ciąg ani, jak i takimi, w których ten ciąg nie występuje. Por.

(8) Na krok nie ruszy się ode mnie.

(9) Nie odstępowała mnie ani na krok, jak stara, brzydka, zazdrosna żona.

(10) O krok nie odstąpię od swoich zasad!

(11) Począłem się obawiać, że książka moja nie posunie się ani o krok do szczęśliwego końca.

W ISJP element ani nie jest w ogóle uznawany za część omawianych jednostek. Do takiego stanowiska jestem skłonna się przychylić. Dlaczego? Fakultatywność jakiegokolwiek ciągu w jednostce leksykalnej rozumiem jako możliwość wystąpienia tego ciągu we wszystkich kontekstach, w których może się pojawić dana jednostka, a jednocześnie możliwość opuszczenia tego ciągu we wszystkich tych kontekstach bez zmiany znaczenia. W poprzednim akapicie starałam się udowodnić, że nie ma takich kontekstów, w których dla omawianych propozycji jednostek ciąg ani byłby obligatoryjny. Istnieją jednak takie zdania, w których obok ciągów na krok i o krok ciąg ani wystąpić nie może - w przeciwnym razie zakłócona zostanie ich sensowność. Por. 
(12) Gdybym ruszyła się na krok ze swojego stanowiska pracy, ktoś natychmiast doniósłby o tym szefowi.

(12a) *Gdybym ruszyła się ani na krok ze swojego stanowiska pracy, ktoś natychmiast doniósłby o tym szefowi.

(13) Rusz się stąd na krok, a popamiętasz!

(13a) *Rusz się stąd ani na krok, a popamiętasz!

(14) Czy on ją choćby na krok odstępuje?

(14a) *Czy on ją choćby ani na krok odstępuje?

(15) Czy jesteś w stanie chociaż o krok odstąpić od swoich zasad?

(15a) *Czy jesteś w stanie chociaż ani o krok odstąpić od swoich zasad?

Dewiacyjność powyższych zdań jest wynikiem właściwości składniowych i semantycznych partykuły ani. Zarówno ani spójnikowe, jak i to, które pełni w zdaniach funkcję partykuły, implikuje negację. Interesujące mnie partykułowe ani poprzedzające frazy przyimkowe na krok i o krok może wystąpić jedynie w zdaniach, w których forma czasownika jest poprzedzona operatorem negacji ${ }^{3}$ nie. Ciągów o krok i na krok można natomiast bez przeszkód użyć w zdaniach, w których negacja - przynajmniej formalnie - nie występuje (por. zdania (12), (13), (14) i (15)). Prócz tego, w zdaniach z negacją partykułowe ani może być nie tylko pominięte, ale też zastąpione nie implikującą negacji partykułą nawet. Por.

(9a) Nie odstępowała mnie nawet na krok, jak stara, brzydka, zazdrosna żona.

Nadal nierozwiązany pozostaje jednak problem ustalenia granic jednostek. Czy można przyjać, że zgodnie z ISJP jednostkami są po prostu na krok i $o k r r o k^{4}$ ? Nie jest bowiem jasne, czy w odniesieniu do wspomnianych wyżej konstrukcji należy traktować ciąg krok jako formalny wykładnik jednostki, czy całości leksykalne tworzy on dopiero z elementami przyimkowymi

3 Takie nie w literaturze językoznawczej tradycyjnie nazywane jest partykułą. O nie jako operatorze negacji pisali M. Grochowski (Grochowski 2007) i S. Żurowski (Żurowski 2006).

${ }^{4}$ O jednostkowym charakterze wyrażenia o krok pisze B. Milewska (Milewska 2003) w kontekście tzw. przyimków wtórnych. Nie kwestionuję konieczności wyodrębnienia takiej grupy wyrażeń. W wyznaczaniu granic jednostek kluczowa jest dla mnie jednak nieregularność semantyczna i/lub syntaktyczna, o której w wypadku omawianego połączenia nie można mówić. 
o i na (zgodnie z propozycją ISJP). Kluczowa jest możliwość zrekonstruowania znaczenia kroku w tych właśnie połączeniach.

Przede wszystkim zauważyć więc trzeba, że w interesujących mnie w tym miejscu kontekstach słowo krok często daje się zamienić innym słowem (lub ciągiem słów), będącym określeniem jakiejś długości. Por.

(16) Nieznajomy zatrzymał się o krok od posłania.

(16a) Nieznajomy zatrzymał się o metr od posłania.

(17) Lecz astrogator cofnął się tylko o krok.

(17a) Lecz astrogator cofnął się tylko o pół metra.

(18) Dymek zapłacił i uskrzydlony biegł o krok przed nią.

(18a) Dymek zapłacił i uskrzydlony biegł o parę centymetrów przed nią.

W powyższych przykładach znaczenie kroku jest dosłowne. Bez wątpienia mamy w nich do czynienia z połączeniami jednostek; z jednoelementowa jednostką leksykalną o postaci krok - w znaczeniu: 'odległość, o jaką posuwa się idący za każdym stąpnięciem' (USJP) - i z jednoelementowymi jednostkami leksykalnymi o i $n a$. Jednak nie we wszystkich kontekstach przypisanie znaczenia krokowi jest tak proste. Por.

(19) Lecz domyślasz się, jak łatwo przy podobnym spojrzeniu posunąć się o krok za daleko i twierdząc, że każdy człowiek jest inny, jedyny i niepowtarzalny, zatrzeć pomiędzy ludźmi wszelką wspólnotę.

(19a) ?Lecz domyślasz się, jak łatwo przy podobnym spojrzeniu posunąc się o odległość, o jaką posuwa się idący za każdym stąpnięciem za daleko i twierdząc, że każdy człowiek jest inny, jedyny i niepowtarzalny, zatrzeć pomiędzy ludźmi wszelką wspólnotę.

W zdaniu (19) nie chodzi oczywiście o określenie za pomocą słowa krok żadnej wartości wymiernej fizycznie, choć źródeł użytej tu metafory należałoby się doszukiwać najpewniej właśnie w tym znaczeniu, które w identycznych formalnie konstrukcjach analizowanych wcześniej tak łatwo dało się wydobyć. Okazuje się bowiem, że w tym samym zdaniu krok zastąpić można wykładnikiem konwencjonalnej jednostki miary, którego znaczenia w tym kontekście również nie należy rozumieć dosłownie, a całe zdanie nie zmieni swojego znaczenia. Por. 
(19b) Lecz domyślasz się, jak łatwo przy podobnym spojrzeniu posunąć się o centymetr za daleko i twierdząc, że każdy człowiek jest inny, jedyny i niepowtarzalny, zatrzeć pomiędzy ludźmi wszelką wspólnotę.

Podobnie w zdaniach:

(20) Od wakacji nie ruszyłam z pracą nawet o krok.

(20a) Od wakacji nie ruszyłam z pracą nawet o pół centymetra.

(21) Ależ jesteś uparty, nie ustępujesz ani na krok.

(21a) Ależ jesteś uparty, nie ustępujesz ani na milimetr.

Oczywiście w takich kontekstach nie można zastąpić kroku jakąkolwiek konwencjonalną jednostką długości (czy jakimkolwiek złożonym jej określeniem), a jedynie takimi wartościami, które konotują „krótkość”. O ile w wielu zdaniach krok zastąpić można centymetrem czy milimetrem, to decymetr czy metr użyte w tych samych miejscach będą tworzyć połączenia bardzo dziwne. Por.

(19c) ?Lecz domyślasz się, jak łatwo przy podobnym spojrzeniu posunąć się o decymetr za daleko i twierdząc, że każdy człowiek jest inny, jedyny i niepowtarzalny, zatrzeć pomiędzy ludźmi wszelką wspólnotę.

(20b) ?Od wakacji nie ruszyłam z pracą nawet o pół metra.

(21b) ?Ależ jesteś uparty, nie ustępujesz ani na metr.

Zdania, w których występują powyższe konstrukcje, łączy jeszcze jeden fakt, o którym warto wspomnieć. Chodzi mianowicie o ograniczenie możliwości ich występowania, wynikające z właściwości semantycznych czasowników konstytuujących zdania z tymi konstrukcjami. We wszystkich zdaniach, w których mogą one wystąpić, znajdujemy pierwotny czasownik ruchu, użyty w znaczeniu wtórnym (metaforycznym). Próby użycia tych konstrukcji w zdaniach, w których nie ma czasownika ruchu (użytego w pierwotnym lub wtórnym znaczeniu), prowadzą do powstania zdań dewiacyjnych. Por.

(22) *Marek jest uparty jak osioł - na krok nie zmieni swojego zdania.

Najpewniej powodem wyodrębnienia przez słowniki języka polskiego jednostek dwuelementowych o krok i na krok (i większych, opartych na tych samych ciaggach) była właśnie trudność przypisania znaczeń poszczególnym elementom, spowodowana metaforyzacją całych fraz czasownikowych. Są- 
dzę jednak, że również w tych kontekstach ciągi o krok i na krok reprezentują nie dwuelementowe jednostki języka, a połączenia jednostek. Po pierwsze dlatego, że - jak pokazują wcześniejsze przykłady - przyimki o i na przyłączają w tych samych kontekstach prócz kroku inne elementy. Po drugie dlatego, że praktycznie niemożliwe jest wyodrębnienie znaczenia całości (jako bytów niepodzielnych): o krok i na krok. ISJP rejestruje je jako jednostki, w których strukturę semantyczną wpisana jest negacja i ilustruje jedynie takimi przykładami, w których negacja występuje formalnie. Por. o krok, na krok.

(D1) 'Jeśli ktoś nie rusza się skądś ani na krok, to w ogóle nie odchodzi stamtąd.' Na krok nie ruszy się ode mnie... Nie odstępowała mnie ani na krok, jak stara, brzydka, zazdrosna żona.

(D2) 'Jeśli jakieś działania nie posunęły się o krok lub na krok, to nie nastąpił w nich żaden postęp.' Poczq̨tem się obawiać, że ksiażka moja nie posunie się ani o krok do szczęśliwego końca... Nie udało mi się posunqć sprawy nawet na krok.

(D3) 'Jeśli ktoś ani o krok lub na krok nie zmienił swoich poglądów, to nie zmienił ich wcale.' O krok nie odstapię od swoich zasad!... Ależ jesteś uparty, nie ustęujesz ani na krok.

Możliwe jest jednak znalezienie takich kontekstów, w których występują interesujące mnie połączenia, a w których zarówno w warstwie formalnej, jak i semantycznej nie ma negacji. Por.

(23) W naszym rozumowaniu posunęliśmy się do przodu zaledwie o krok.

(24) Gdy odstępowałam go choćby na krok, zaczynał płakać.

Nie należy, jak sądzę, doszukiwać się nowego, utrwalonego w języku znaczenia dla słowa krok. We wszystkich przykładach, w których pojawiają się ciagi o krok i na krok, doszukiwałabym się raczej znaczenia dosłownego, ewentualnie użycia metaforycznego ${ }^{5}$ jednoelementowej jednostki leksykalnej o postaci krok.

5 Przez użycie metaforyczne rozumiem za E. Rudnicką metaforę okazjonalną ,zrozumiała jedynie dzięki przywołaniu motywującego znaczenia realnego" (Rudnicka 2004: 46), dla której „nie ma i nie powinno być miejsca w słownikach ogólnych” (Rudnicka 2004: 45). 
Jeżeli natomiast chodzi o wymienność ciągów o krok i na krok w konkretnych zdaniach, to jej ograniczenie wynika jedynie z właściwości przyimków $o$ i na. W omawianych połączeniach łączliwość tych przyimków jest regularna.

Krótkiego omówienia wymagają jeszcze trzy propozycje jednostek, o których dotąd nie wspomniałam. Obok omówionego już przeze mnie ciągu (ani) na krok, który reprezentować miał osobną jednostkę leksykalną lub miał być częścią większych jednostek leksykalnych, w słownikach znaleźć można jeszcze jeden ciąg, nierzadko traktowany jako ekwiwalent powyższego. Chodzi mianowicie o rejestrowanie propozycji frazeologizmów, w których zasugerowana jest wymienność ciągów (ani) na krok i krokiem (por. przykł. (c), (f), (j), (l)). Pierwszy z tych ciągów został omówiony wcześniej; w przytoczonych propozycjach związków frazeologicznych jest jedynie elementem większej konstrukcji syntaktycznej, a nie częścią wykładnika jednostki leksykalnej. Nieco inaczej wygląda problem drugiego z nich. Ciag ten można rozpatrywać jako jednoelementową jednostkę leksykalną o postaci krok bądź jako czessć związków frazeologicznych. W słownikach ciąg krokiem (nieprzyłączający formy przymiotnikowej) notowany jest w trzech otoczeniach (jako część trzech frazeologizmów):

(m) nie ruszyć się [skadś] krokiem (USJP, SJPSz, SJPDor, MSJP, WSJP, SFzB, WSFzp, PSF),

(n) postapić krokiem (WSFzp, SFJP),

(o) nie pójść [skąś'] krokiem (MSJP).

Za tym, by traktować ciąg krokiem jako część wykładników większych całości leksykalnych, przemawia przede wszystkim to, że nie jest on wymienny na żaden inny rzeczownik w formie narzędnika określający długość czy nawet sposób przemieszczania się człowieka. Por.

(25) Jan nie ruszył się z domu krokiem.

(25a) *Jan nie ruszył się z domu metrem/centymetrem.

(25b) *Jan nie ruszył się z domu skokiem.

Nie chcę jednak zagłębiać się $\mathrm{w}$ analizę powyższych jednostek, ponieważ wszystkie trzy uważam za przestarzałe. Moim celem jest natomiast wyodrębnienie jedynie tych jednostek, które należą do współczesnego języka polskiego. Choć pierwszą z wymienionych jednostek notują prawie wszystkie 
z przeanalizowanych przeze mnie słowników, to przykładów jej użycia nie ma w korpusach (podobnie jak trzeciej z powyższych propozycji). Jedyny kontekst rejestrujący użycie drugiej jednostki, to fragment tekstu wyraźnie stylizowanego:

(26) Ręce chłopu mdleją, pot oczy zalewa, krzyż mało nie pęknie od dźwigania wciąż rosnącego ciężaru. Wreszcie już ni krokiem postąpić nie może, tak mu ciąży ten chleba bochen. Alboż to chleb jest?

Jednostkę o kształcie być (o) krok od [czegoś] notują USJP, WSFzp i SFWP (ten ostatni bez fakultatywnego $o$ ). Nie ma jej natomiast w pozostałych słownikach. W moim przekonaniu powyższy ciąg jest reprezentacją rzeczywiście istniejącej jednostki, tyle że funkcjonuje ona w języku polskim obok formalnie identycznej konstrukcji. Podstawową różnicą jest w tym wypadku pewne ograniczenie semantyczne, tj. możliwość wypełnienia drugiego miejsca walencyjnego (przy założeniu, że omawiana jednostka jest dwuwalencyjna - [ktoś] jest o krok od [czegoś]). Jednostka leksykalna otwiera je jedynie dla rzeczowników abstrakcyjnych ${ }^{6}$. Por.

(27) Dotychczasowe badania DNA prowadzone na znacznie mniejszych próbkach pozwalają bowiem przypuszczać, że co najmniej trzy razy w historii planety byliśmy o krok od podzi ele n ia smętnego losu dinozaurów.

(28) Kobieta była o krok od śmiertelnego w y krwawienia.

(29) U progu XXI wieku jesteśmy o krok od stworzenia specyfików zapewniających długowieczność.

Oczywiście w kontekstach typu:

(30) W 1928 r. o krok od medalu był Bronisław Czech w St. Moritz., w których drugie miejsce walencyjne przeznaczone jest dla rzeczownika abstrakcyjnego, a formalnie jest tam rzeczownik konkretny, mamy do czynienia

${ }^{6}$ Podział na rzeczowniki abstrakcyjne i konkretne jest w tym miejscu bardzo dużym uproszczeniem. Jednostka leksykalna [ktoś] jest o krok od [czegoś] drugie miejsce walencyjne otwiera przeważnie dla fraz nominalnych konstytuowanych przez rzeczowniki derywowane od czasowników dokonanych. Mogą tam się jednak pojawić także frazy nominalne, w których konstytuujący je rzeczownik nie jest derywatem odczasownikowym (por. być o krok od śmierci, być o krok od katastrofy, ale: *być o krok od agresji). 
z pewnym skrótem myślowym. Każdy z tego typu kontekstów może zostać rozwinięty. Por.

(30a) W 1928 r. o krok od zdobycia medalu był Bronisław Czech w St. Moritz.

Jednostką zbliżoną do [ktoś] jest (o) krok od [czegoó́ formalnie i, jak sądzę, identyczną semantycznie jest jednostka [ktoś] jest (o) włos od [czegoś]. Drugie miejsce walencyjne tej jednostki również może być wypełnione jedynie przez frazę rzeczownikową, konstytuowaną przez rzeczownik o charakterze abstrakcyjnym. Nie znajduję przykładów zdań, w których jednostki [ktoś] jest (o) krok od [czegoś] i [ktoś] jest (o) włos od [czegoś] nie mogłyby być użyte wymiennie. Żadne z poniższych zdań nie wydaje się w jakikolwiek sposób gorsze od pozostałych. Por.

(31) Nasi chłopcy byli tym razem o krok od wygranej.

(31a) Nasi chłopcy byli tym razem o włos od wygranej.

(32) Dwa razy w życiu byłam o krok od śmierci.

(32a) Dwa razy w życiu byłam o włos od śmierci.

(33) I pomyśleć, że ten zły człowiek był o krok od uniknięcia odpowiedzialności za swoje zbrodnie!

(33a) I pomyśleć, że ten zły człowiek był o włos od uniknięcia odpowiedzialności za swoje zbrodnie!

Niemożliwe jest natomiast zastąpienie konstrukcji [ktoś] jest (o) krok od [czegoś] konstrukcją [ktoś] jest (o) włos od [czegoś]. Por.

(34) Czujesz się samotny, choć bliskie osoby są o krok od ciebie.

(34a) *Czujesz się samotny, choć bliskie osoby są o włos od ciebie.

Na uwagę zasługuje jeszcze pewna różnica formalna między omawianymi jednostkami. W strukturze formalnej jednostki [ktoś] jest (o) włos od [czegoś] może pojawić się dodatkowy element - forma przymiotnikowa mały. Por.

(35) Niekiedy byłam o włos od katastrofy, przy czym groziło mi na zmianę rozbicie się o kamienną ścianę albo runięcie na zbity pysk w przepaść.

(35a) Niekiedy byłam o mały włos od katastrofy, przy czym groziło mi na zmianę rozbicie się o kamienną ścianę albo runięcie na zbity pysk w przepaść. 
Ta różnica ma jednak charakter jedynie formalny. Między powyższymi zdaniami nie zachodzi żadna dyferencja semantyczna. Nie ma żadnych podstaw, by sądzić, że nadawca drugiej wypowiedzi był bliższy katastrofy, niż nadawca wypowiedzi pierwszej.

W wypadku jednostki [ktoś] jest (o) krok od [czegoś] każdy dodany element przymiotnikowy byłby ,ciałem obcym” w tej jednostce. Por.

(36) Kobieta była o krok od śmiertelnego wykrwawienia.

(36a) ?Kobieta była o mały krok od śmiertelnego wykrwawienia.

Kategoryczne stwierdzenie dewiacyjności powyższego zdania byłoby nadużyciem. $Z$ całą pewnością można jednak mówić o tym, że jest ono dziwne, a dodany element wyraźnie „odstaje” od leksykalnej całości. Zmiana dokonana w jednostce leksykalnej nie jest w tym wypadku niczym regularnym. Pojawienie się tego typu przekształceń w wypowiedziach może być spowodowane nieznajomością formy związku frazeologicznego, ewentualnie chęcią podkreślenia jakiejś treści (w tym wypadku tego, jak niewiele dzieliło kogoś od śmiertelnego wykrwawienia). Wspomniane przekształcenie należy traktować raczej jako przykład innowacji frazeologicznej, niż jako systemowe użycie jednostki języka.

Jak wykazała powyższa analiza, ze sporej grupy wyrażeń, wyodrębnionych przez słowniki jako osobne jednostki opisu, zdecydowaną większość należy uznać za konstrukcje syntaktyczne. Istnieje jedynie jedna wielosegmentowa jednostka leksykalna, w której reprezentację formalną wpisany jest ciąg (o) krok. Wyrażenie na krok w każdym kontekście należy interpretować jako konstrukcję syntaktyczną.

\section{Objaśnienia skrótów}

ISJP - Bańko M. (red.), Inny słownik języka polskiego, t. 1-2, Warszawa 2000: Wydawnictwo Naukowe PWN.

MSJP - Sobol E. (red.), Maty stownik języka polskiego, Warszawa 1993: Wydawnictwo Naukowe PWN.

PSF - K. Głowińska, Popularny stownik frazeologiczny, Warszawa 2000: Wydawnictwo Wilga.

SFJP - Skorupka S., Stownik frazeologiczny języka polskiego, t. 1, Warszawa 1977: Państwowe Wydawnictwo Wiedza Powszechna. 
SFWP - Bąba S., Liberek J., Stownik frazeologiczny wspótczesnej polszczyzny, Warszawa 2001: Wydawnictwo Szkolne PWN.

SFzB - Sobol E. (red.), Stownik frazeologiczny PWN z Bralczykiem, Warszawa 2008: Wydawnictwo Naukowe PWN.

SJPDor - Doroszewski W. (red.), Stownik języka polskiego, Warszawa 1997: Wydawnictwo Naukowe PWN [CD-ROM].

SJPSz - Szymczak M. (red.), Stownik języka polskiego, Warszawa 1978-1981: Wydawnictwo Szkolne PWN.

USJP - Dubisz S. (red.), Uniwersalny stownik jezzyka polskiego, Warszawa 2003: Wydawnictwo Naukowe PWN.

WSFzp - Dubisz S., Sobol E. (red.), Wielki stownik frazeologiczny PWN z przystowiami, Warszawa 2005: Wydawnictwo Naukowe PWN.

WSJP - Dunaj B. (red.), Współczesny słownik języka polskiego, Warszawa 2007: Langenscheidt.

\section{Bibliografia}

Grochowski M., 1982, Zarys leksykologii i leksykografii. Zagadnienia synchroniczne, Toruń: Wydawnictwo UMK.

Grochowski M., 2007, O kwalifikacji gramatycznej jednostek o postaci nie, w: J. Kamper-Warejko, J. Kulwicka-Kamińska, K. Nowakowska (red.), Z przeszłości i teraźniejszości języka polskiego. Księga pamiątkowa ofiarowana Teresie Friedelównie, Toruń: Wydawnictwo Naukowe UMK, s. 271-279.

Milewska B., 2003, Przyimki wtórne we współczesnej polszczyźnie, Gdańsk: Wydawnictwo UG.

Rudnicka E., 2004, Znaczenie metaforyczne w polskiej tradycji stownikarskiej, Warszawa: Wydawnictwo Naukowe Semper.

Żurowski S., 2006, Jednosegmentowe jednostki leksykalne o postaci nie, Polonica, t. 26-27, s. 131-146. 
Syntactic and semantic analysis of the expressions o krok and na krok

\section{( su m m a r y)}

The article provides an analysis of the units of description with forms na krok and $o$ krok, as they are described by general Polish dictionaries and dictionaries of set phrases. The analysis aims to distinguish all lexicological units in Polish are constituted by the aforementioned sequences. The author singles out one multi-elemental lexical unit of contemporary Polish ([ktoś] jest (o) krok od [czegoś] '[somebody] is close/near to [something]'), while all the remaining expressions are considered to be syntactical constructions. 